\title{
Experiences in Supply Chain Quality Management Practices in Vietnam: Studying on Steel Manufacturing Company A and Packaging Manufacturing Company B
}

\author{
Nguyen Thi Duc Nguyen ${ }^{1}$ \\ ${ }^{1}$ Ho Chi Minh City University of Technology-VNU-HCM, Vietnam \\ Correspondence: School of Industrial Management, Ho Chi Minh City University of Technology-VNU-HCM, \\ Vietnam. E-mail: ntdnguyen@hcmut.edu.vn; ntducnguyen@yahoo.co.jp
}

Received: April 1, 2019

doi:10.5539/ijbm.v14n7p171
Accepted: May 26, 2019

Online Published: June 23, 2019

\begin{abstract}
Supply chain quality management is receiving the increasing interests of managers not only in Vietnam, but also in over the world, though research to date insufficiently meets the practical needs of business. Taking an advantage, this study aims at providing practical experiences in supply chain quality management practices of companies in Vietnam which effectively effects on their firm's performance. On the basis of reviewing previous studies, this study is conducted through in-depth interviewing with seven experts of the seven manufacturing companies in Vietnam and researching case study at two typical manufacturing companies in the steel and packaging manufacturing industry in Vietnam. The result finds that there are six critical aspects of supply chain quality management practices having the impact on firms' performance in Vietnam, specifically top management support, human resource development, internal lean practices, supplier focus, strategic supplier partnership and customer focus. Finally, it provides an interesting reference for supply chain managers in Vietnam in searching the appropriate approaches to increase the performance of the business through supply chain quality management practices.
\end{abstract}

Keywords: Supply chain management (SCM), Supply chain quality management (SCQM), Steel manufacturing, Packaging manufacturing, Vietnam

\section{Introduction}

Nowadays, businesses increasingly use the supplier's network to produce, distribute products and services to customers. The specific functions of the previous supply chain are buying, producing, supporting activities in logistic, etc., which are no longer adequate to meet customer need. Controlling what happens in the supply chain outside businesses, especially related to quality, is becoming more and more difficult.

The fact that the participation in current ASEAN economic communities or Trans-Pacific Economic Partnership Agreement provides opportunities to join the global supply chain but also creates many challenging competition for Vietnam in cost, quality, product improvement, inventory, etc. Vietnamese businesses need to be confident and proactive in finding opportunities to establish trustworthy partnerships in the supply chain, considering innovation, creativity is a major orientation to invest in technology, high-level human resources training and development. The problems of many Vietnamese companies are the thinking of small businesses is inherent, they just think that participating in the supply chain is handling, assembly and processing and, they face with the lack of resources and knowledge about supply chain quality performance management. Therefore, businesses can achieve success if they can construct, manage an effective supply chain like Vingroup, a leading economic group in Vietnam, which is multi-sector business, for the last 2 years developing networks with hundreds of supermarkets throughout the country and invest in high-tech agriculture in many localities (Nguyen, 2016). In addition, the product life cycle is shorter and the increase of product category need creates complex in the supply chain. The partners in the supply chain are trying to minimize costs and maximize service levels. Accordingly, to increase competitiveness, innovation needs to be invested in supply chain management to create a breakthrough to ensure the new customer attraction, increase market share, and attack new markets. Therefore, each process in the supply chain must coordinate and integrate with each other (Nguyen et al., 2017).

At the same time, the matter of quality management in the supply chain is being paid more and more attention on 
its importance by previous studies. Some studies have defined the concept of supply chain quality management (SCQM) and identified the important topics in this area (e.g., Robinson \& Malhotra, 2005), the relationship between quality management and supply chain quality management practices and their effects on organizational or supply chain operations (e.g., Flynn \& Flynn, 2005; Lo et al., 2007; Kaynak \& Hartley, 2008), etc. Therefore, SCQM contributes to increasing the performance of businesses, as well as the competitiveness of businesses with the changes of business environment as the ongoing globalization process. With the opportunities to participate in global supply chains, identifying the components of SCQM on the performance of businesses will help managers have a basis to proceed SCQM to increase competitiveness with international businesses and sustainable development.

Actually, up to date, the prevailing studies approach SCQM under three prominent perspectives with advantages and disadvantages, including supply chain management and quality management, supply chain management with the implementation of Lean and supply chain management in the innovation process (Nguyen et al. 2017). Overall, most of the existing research on three mentioned perspectives mainly investigates within the manufacturing sector in developed countries, and they give much attention to supply chain fulfillment; few studies focus on supply chain development and lack the combination (Nguyen et al. 2017). For this reason, it is necessary to identify the key factors of SCQM that contribute to the performance of the business, especially, learning through successfully practical SCQM cases in Vietnam. This helps companies in Vietnam achieve increasing competitiveness in the context of changing business environment.

\section{Theoretical Background}

By literature review, the comprehensive implementation of SCQM consists of three aspects: upstream, internal process and downstream. On the basis of supply chain management and quality management perspective, there are various aspects of SCQM. For example, according to Kuei and Madu (2001), SCQM includes various aspects: top management and leadership, training, product designing, supplier quality management, process management, quality data reports, employee relationship, customer relationship, benchmarking, supplier selection and participation, information technology, IT oriented, and integrated operation process. Similarly, following by Azar et al. (2010), 6 quality management elements related to supply chain implementation are leadership, strategic plan, human resource management, supplier quality management, customer focus, and process management. Lin et al. (2013) also defined elements of SCQM as supplier relationship, information technology, process management, top management support, human resource management, strategy planning, and knowledge management. Currently, there are some previous studies closely related to the matter of SCQM facilitators which are the fundamental for this study, which are summarized, classified into six dimensions, including top management support (e.g., Zhang et al., 2000; Lin et al., 2004; Lo et al., 2007; Lin \& Gibson, 2011; Zeng et al., 2013; Nosratpour \& Hamid, 2015; Soares et al., 2017); human resource development (e.g., Zhang et al., 2000; Kaynak \& Hartley, 2008; Chaghooshi et al., 2015; Nosratpour \& Hamid, 2015; Soares et al., 2017); the internal lean practices (e.g., Zhang et al., 2000; Kannan \& Tan, 2005; Okoth \& Ochieng, 2016); supplier focus (e.g., Zhang et al., 2000; Sila et al., 2006; Soares et al., 2017); strategic supplier partnership (e.g., Zhang et al., 2000; Kannan \& Tan, 2005; Zeng et al., 2013; Okoth \& Ochieng, 2016; Soares et al., 2017) and customer focus (e.g., Sila et al., 2006; Lo \& Yeung, 2006; Chaghooshi et al., 2015; Nosratpour \& Hamid, 2015; Soares et al., 2017).

Overall, it is shown that almost all previous research on the connection of supply chain management and quality management perspective affirm the significant role and great influence of SCQM on the firm's performance. However, they have insufficient facilitators, the role of other functions, lack sufficient attention on both upstream and downstream-oriented quality activities, and organization learning within partners in the supply chain. Moreover, most of the existing research on the mentioned perspectives mainly investigates within the manufacturing sector in developed countries, and they give insufficient attention to the whole supply chain as well as industry in developing countries (Nguyen et al., 2017).

\section{Research Methodology}

Following the Creswell (2009)'s approach, this study is conducted through: (a) reviewing previous studies; (b) in-depth interviewing with experts of the seven manufacturing companies and (c) researching case study at two typical manufacturing companies in the steel and packaging manufacturing industry in Vietnam.

The literature review is done to review the facilitators of the supply chain quality management from previous studies. Theoretical research methods mainly aim at seeking information from previous studies related to the content and research topic.

Then, the in-depth interviews are carried out with seven experts in the industry to explore the insight, opinions and judgments of the experts and identify the critical factors for supply chain quality management success. The 
interviewees are the supply chain managers, department supervisor related to company's supply chain with at least 3-years' experience working on supply chain quality management (in this study, interviewees have mean 5 -years' SCQM working experience) at seven manufacturing companies. The in-depth interviews are done on the basis of the semi-structured questionnaire which is designed for interviewing directly with the experts. Each conversation takes at least one and a half hours and the content is recorded and noted. Information and data are collected, rewritten, classified and presented carefully after each interview. Then, the data are analyzed and synthesized in the results.

Two typical company cases are the Steel company (Company A) and the packaging company (Company B).

\section{Steel Company-A}

Steel Company A is the first company to be invested abroad by the B-steel Group with a total investment of about 86 million USD. Currently, Company A has been operating for 6 years in Binh Duong and gradually improving the factory.

The company has a factory in Binh Duong produces iron, steel, aluminum packaging (aluminum cans) typed of $330 \mathrm{ml}$ and $500 \mathrm{ml}$ to supply to the domestic market and export in Vietnam - Singapore Industrial Park IIA, Tan Uyen, Binh Duong with a capacity of over 700 million cans/year.

The factory in Binh Duong is built to meet the needs of expanding the B-steel Group's production scale. The issues of quality management and supply chain management are applied in the company to ensure product quality as well as supply chain management effectiveness. At the same time, the supply chain quality management helps the company penetrate into the market of carbonated beverage, beer, energy drinks and juices in Southeast Asia such as Cambodia, Thailand, and Malaysia, etc.

Besides, the team of experts and leaders from the B-steel Group were sent to manage and operate the factory in Binh Duong. This helps to improve efficiency at the factory and improve the supply and quality throughout the supply chain.

\section{Packaging Company-B}

Packaging Company B is a company specialized in the production of plastic products and key products of all kinds of woven packaging. In addition, from the experience of manufacturing 20-200 kg bags for agricultural production and consumer goods, the company is turning to producing containers of 500-2000 $\mathrm{kg}$ containers for export industry.

With long-term experience in plastic industry, diversified products of high quality, the company B has more than 15 foreign customers and more than 80 domestic customers. At the same time, Company B exports products to 25 countries in Europe, Asia, Africa, and America.

The company is constantly researching and applying advanced technology to produce new products, lower prices, and desire to meet the increasing and the diverse requirements of customers. Through this process, SCQM is concerned with businesses to achieve business efficiency and towards sustainable supply chain development.

Overall, the review of previous studies aims to find out the key elements for implementing successful SCQM. Then, based on the result of the literature review, the in-depth interviews, and case study research, this study aims to identify the critical factors of SCQM leading to the firm's performance of companies in Vietnam.

\section{Results}

On the basis of the in-depth interviews and two case studies, this section summarizes the collected data and the analysis performed the key factors of SCQM affecting firm's performance, specifying at top management support (Table 1), human resource development (Table 2), internal lean practices (Table 3), supplier focus (Table 4), strategic supplier partnership (Table 5), and customer focus (Table 6).

\subsection{Top Management Support}

The results show that top management support reflects on participation of top management, focusing on product quality rather than output, encouraging employees to participate in quality-related processes, encouraging participation, and empowering suppliers to deal with quality management activities. The evidence is that the experts and two company cases almost agree (Table 2). However, in the case B, there are also opinions, disagreeing with the leadership of the company to empower suppliers to solve quality management activities. According to Quality Innovation Part of the production department in Case B, the company completely controls the quality of suppliers and makes requests in quality management activities, but still invites/encourages 
suppliers to have meetings and training requirements for quality management and improvement.

Table 1. Aspects of top management support in SCQM

\begin{tabular}{|c|c|c|c|}
\hline $\begin{array}{c}\text { Aspects of top } \\
\text { management support }\end{array}$ & In-depth & Case A & Case B \\
\hline $\begin{array}{l}\text { Top management } \\
\text { actively participates in } \\
\text { quality management and } \\
\text { improvement process. }\end{array}$ & $\begin{array}{l}\text { The competitive pressure in the } \\
\text { industry is increasingly fierce, } \\
\text { so the factories usually have a } \\
\text { manager to supervise the } \\
\text { quality-related stages. } \\
\text { The participation and support } \\
\text { of resources to implement } \\
\text { SCQM, expressed by the } \\
\text { management, represents a } \\
\text { higher level of commitment. }\end{array}$ & $\begin{array}{l}\text { The supply chain is a process } \\
\text { having many activities. So, top } \\
\text { management involved in managing } \\
\text { through the company's web-based } \\
\text { system. Through it, the management } \\
\text { of SCQM will be flexible and be } \\
\text { able to keep track of what is } \\
\text { happening in the supply chain of the } \\
\text { business. }\end{array}$ & $\begin{array}{l}\text { The top management will play a } \\
\text { more oriented role. When top } \\
\text { management has a quality } \\
\text { perspective on the supply chain, } \\
\text { they will lead people to follow the } \\
\text { supply chain quality routes } \\
\text { exactly. And of course, top } \\
\text { management's participation will } \\
\text { be really necessary rather than } \\
\text { only giving the general vision and } \\
\text { strategy. }\end{array}$ \\
\hline $\begin{array}{l}\text { Top management } \\
\text { strongly encourages } \\
\text { employee involvement in } \\
\text { quality management and } \\
\text { improvement activities }\end{array}$ & $\begin{array}{l}\text { Top management is the first } \\
\text { people demonstrating their } \\
\text { responsibility for the } \\
\text { implementation of SCQM, } \\
\text { supporting the motivation to } \\
\text { members of the business. }\end{array}$ & $\begin{array}{l}\text { Through the monthly salary and } \\
\text { reward policies implemented by top } \\
\text { management to encourage and } \\
\text { motivate employees to participate in } \\
\text { SCQM. }\end{array}$ & $\begin{array}{l}\text { Top management is not a pure } \\
\text { source of motivation, because } \\
\text { anything will be allocated from } \\
\text { the high to the middle level and to } \\
\text { the levels of execution. Therefore, } \\
\text { when the leadership wants to } \\
\text { implement SCQM, they will lead } \\
\text { the employees and the whole } \\
\text { company to follow. }\end{array}$ \\
\hline $\begin{array}{lr}\text { Top } & \text { management } \\
\text { discusses } & \text { many } \\
\text { quality-related issues in } \\
\text { top } \quad \text { management } \\
\text { meetings }\end{array}$ & $\begin{array}{l}\text { Top management and members } \\
\text { of the supply chain play a main } \\
\text { role in SCQM. }\end{array}$ & $\begin{array}{l}\text { In the meeting between many } \\
\text { departments, this would be a good } \\
\text { place to communicate information } \\
\text { between departments on issues and } \\
\text { improvements in SCQM. On the } \\
\text { business, the meetings take place } \\
\text { according to each department, and } \\
\text { the logistics department of the } \\
\text { company is the same. In addition, } \\
\text { the company will quarterly have } \\
\text { meetings to assist the } \\
\text { implementation of SCQM. }\end{array}$ & $\begin{array}{l}\text { Top management needs to have } \\
\text { verification stage, review the } \\
\text { problems of SCQM in order to } \\
\text { make orientation in the future. } \\
\text { Currently, the needs of customers } \\
\text { change constantly, so they have to } \\
\text { find a right way, and right time. If } \\
\text { the company is late, it will lose the } \\
\text { opportunity in the development } \\
\text { process. }\end{array}$ \\
\hline $\begin{array}{l}\text { Top management } \\
\text { strongly encourages } \\
\text { supplier involvement in } \\
\text { quality management and } \\
\text { improvement activities }\end{array}$ & $\begin{array}{l}\text { In the companies, they often } \\
\text { organize quality events and } \\
\text { large companies require their } \\
\text { suppliers to attend and train } \\
\text { them. } \\
\text { Firms encourage their members } \\
\text { in the supply chain } \\
\text { implementing SCQM to } \\
\text { sustainably develop together. }\end{array}$ & $\begin{array}{l}\text { Top management activities } \\
\text { encouraging the members of the } \\
\text { supply chain are made through } \\
\text { documents, shown on contracts. In } \\
\text { addition, in the meetings with } \\
\text { partners, quality issues of the } \\
\text { supply chain are also discussed, } \\
\text { towards strategic objectives. }\end{array}$ & $\begin{array}{l}\text { This will be a common } \\
\text { commitment. Because the supply } \\
\text { chain will have a reciprocal } \\
\text { impact between the chains and the } \\
\text { entire supply chain. The SCQM } \\
\text { process can only be implemented } \\
\text { when all members of the supply } \\
\text { chain having a common } \\
\text { commitment. }\end{array}$ \\
\hline $\begin{array}{l}\text { Top management } \\
\text { empowers suppliers to } \\
\text { solve quality problems }\end{array}$ & \multicolumn{2}{|c|}{$\begin{array}{l}\text { Top management often empowers suppliers, this help suppliers } \\
\text { discount or recall their products. }\end{array}$} & $\begin{array}{l}\text { The company completely controls } \\
\text { the quality of suppliers and makes } \\
\text { requests in quality management } \\
\text { activities. }\end{array}$ \\
\hline
\end{tabular}

\subsection{Human Resource Development}

As the result, human resource development is a process of training how to use quality management components, educating employee awareness, improving working conditions to create efforts to improve the quality of labor, 
and encouraging employees report and handle quality-related issues. Most experts agree with this factor and show that is the aim of every business (Table 3). Additionally, regard to encouraging employees to solve quality problems, experts also add the notice that the problem depends on its level (low/high) and how low/high it is.

Table 2. Aspects of human resource development in SCQM

\begin{tabular}{|c|c|c|c|}
\hline $\begin{array}{l}\text { Aspects of human } \\
\text { resource development }\end{array}$ & In-depth & Case A & Case B \\
\hline $\begin{array}{l}\text { Most employees in the } \\
\text { company are trained on } \\
\text { how to use quality } \\
\text { management method } \\
\text { (tools) }\end{array}$ & $\begin{array}{l}\text { In order to efficiently manage } \\
\text { quality for a supply chain, it } \\
\text { is necessary to employ } \\
\text { people who are } \\
\text { knowledgeable about SCQM } \\
\text { quite well and have the } \\
\text { necessary attitude to } \\
\text { effectively implement } \\
\text { SCQM. }\end{array}$ & $\begin{array}{l}\text { This is an important factor for the } \\
\text { company. Because it is easier when } \\
\text { they recruit an employee having } \\
\text { SCQM's experience and } \\
\text { understanding. Besides, the internal } \\
\text { training will also help employees } \\
\text { grasp the elements of SCQM. } \\
\text { However, the most important things } \\
\text { are employee's attitude and spirit. It is } \\
\text { also important for this company to } \\
\text { choose a suitable candidate and } \\
\text { develop him/her with their business to } \\
\text { implement SCQM. }\end{array}$ & $\begin{array}{l}\text { The understanding of SCQM of } \\
\text { employees is an advantage in } \\
\text { implementing SCQM but it is not } \\
\text { complete. This is a necessary } \\
\text { condition, but not enough, } \\
\text { because each supply chain will } \\
\text { have different needs and different } \\
\text { customers. As for sufficient } \\
\text { conditions, there is a need to have } \\
\text { a training about the customer and } \\
\text { the company's history. }\end{array}$ \\
\hline $\begin{array}{l}\text { Quality awareness } \\
\text { education is given to } \\
\text { employees. }\end{array}$ & $\begin{array}{l}\text { Through training for } \\
\text { employees to implement } \\
\text { SCQM, it is an effective way } \\
\text { for employees in the } \\
\text { enterprise to understand and } \\
\text { implement SCQM, then } \\
\text { contribute in promoting } \\
\text { business efficiency. } \\
\text { Training through experts or } \\
\text { consultants will help } \\
\text { businesses get an overview } \\
\text { of the market, they play a } \\
\text { role in orienting the direction } \\
\text { of leadership to obtain } \\
\text { SCQM effectively and } \\
\text { achieve business } \\
\text { performance. }\end{array}$ & $\begin{array}{l}\text { Fostering knowledge is always } \\
\text { important. This is one of the factors } \\
\text { promoting SCQM. It is not only the } \\
\text { employees in the company, but also } \\
\text { members of their supply chain from } \\
\text { suppliers of materials, components, } \\
\text { machinery, to transporters... Programs } \\
\text { participating in the quality of } \\
\text { suppliers are planned in detail and } \\
\text { made a clear route to be suitable for } \\
\text { each partner and implement } \\
\text { effectively SCQM with them. } \\
\text { Consultants will have a better } \\
\text { overview than employees in the } \\
\text { company, what new knowledge can be } \\
\text { gained in the market and how the } \\
\text { business can apply that knowledge, } \\
\text { experts offer that for businesses. } \\
\text { Therefore, when businesses need }\end{array}$ & $\begin{array}{l}\text { Certainly, there is a facilitator. } \\
\text { Training must be at a strategic } \\
\text { level. The sustainable } \\
\text { development mainly lies in the } \\
\text { human being that continues from } \\
\text { one generation to the next. From } \\
\text { then on, it is possible to develop } \\
\text { sustainably. } \\
\text { This factor also quite effect to the } \\
\text { company. } \\
\text { management mislead directions, } \\
\text { therefore, they cannot respond } \\
\text { customers' requirements, the } \\
\text { consulting organizations and } \\
\text { experts will be able to correct the } \\
\text { direction more properly. So } \\
\text { management will play a leading } \\
\text { role in the business as well as } \\
\text { supply chain development. }\end{array}$ \\
\hline
\end{tabular}

expert's offers, it is necessary to have consideration for the company that they need an overall view or side view from activities in the supply chain. In the case that the consulting organization can work long term and understand the supply chain, it is better to conduct a consultant organization on SCQM.

The company improves working conditions in order to recognize employee quality improvement efforts.
Solving quality problems in the supply chain by teamwork, therefore helps all members understand the overall work and support each other.

A dynamic working
In the company, an employee cannot know everything about the business. When teamwork includes people who can work together and can consider all components of the supply chain (price, quality, delivery...), the efficiency will be enhanced.
First, there must be a common voice, a consistent commitment and everyone must follow it. When working in teams, you must share different perspectives, not merely solve a problem. Working in teams with the 


\begin{tabular}{|c|c|c|}
\hline & $\begin{array}{l}\text { environment that promotes } \\
\text { innovation and incremental } \\
\text { improvements. Besides, open } \\
\text { working environment for all } \\
\text { employees will be a place for } \\
\text { better SCQM } \\
\text { implementation. }\end{array}$ & $\begin{array}{l}\text { traditional culture of finding who } \\
\text { make mistakes, who is } \\
\text { responsible, this will make the } \\
\text { team not perform well and be } \\
\text { underdeveloped. When supply } \\
\text { chain members are assembled to } \\
\text { share a problem or change, it is a } \\
\text { challenge and when this is done, } \\
\text { the efficiency of SCQM will } \\
\text { affect the efficiency of businesses } \\
\text { and the whole supply chains. } \\
\text { The factor of building a value } \\
\text { system and trust is one of the } \\
\text { important factors in promoting } \\
\text { SCQM and will affect efficiency } \\
\text { in the business. }\end{array}$ \\
\hline $\begin{array}{l}\text { Reporting work } \\
\text { problems is encouraged } \\
\text { in our company }\end{array}$ & \multicolumn{2}{|c|}{$\begin{array}{l}\text { It is encouraging employees report work problems. Then, supply chain quality improvement is one of the } \\
\text { important factors in implementing SCQM in quality improvement projects. }\end{array}$} \\
\hline $\begin{array}{l}\text { Employees are } \\
\text { encouraged to fix } \\
\text { problems they find. }\end{array}$ & $\begin{array}{l}\text { It is necessary to have the participation of employees, along with manager } \\
\text { efficient. } \\
\text { In small and medium The participation of members in } \\
\text { enterprises, employees are SCQM will be a factor promoting } \\
\text { not often encouraged to solve supply chain quality. People are one } \\
\text { quality problems because of the factors that determine and } \\
\text { single production type is very control quality. } \\
\text { important, so it cannot be } \\
\text { solved by individual. } \\
\text { It depends on the type of } \\
\text { industry, especially food } \\
\text { industry, the training of } \\
\text { employees and new } \\
\text { employees is the most } \\
\text { important thing. Because if } \\
\text { there is a problem at any } \\
\text { stage, it can bring heavy } \\
\text { quality damage. }\end{array}$ & $\begin{array}{l}\text { nent so that the SCQM can be more } \\
\text { This is an ideal thing, because the } \\
\text { participation and synchronization } \\
\text { of employees will help the SCQM } \\
\text { process be implemented more } \\
\text { effectively, thereby promoting } \\
\text { efficiency for businesses. Since } \\
\text { each supply chain has different } \\
\text { components and parts, } \\
\text { synchronization and consistency } \\
\text { will help the whole system and } \\
\text { business grow better. }\end{array}$ \\
\hline
\end{tabular}

\subsection{Internal Lean Practices}

It is shown that the internal lean practices are the processes that usually performs quality checks, sets standard components, costs that are emphasized in the product design process, as well as constantly improves the quality of system and service. In addition, some experts also emphasize the employee's inspection from the process of working more frequently at each stage.

Some experts suggest that the second aspect should be adjusted to understand easier "Our process applies different quality standards, according to the regulations of the product's composition ". And in the third aspect should be added the further explanation, as "Reducing redundant design/process, but still ensuring quality" because if you use the phrase "Cost is emphasized" the respondents may not appreciate because they don't know if this cost is related to quality. 
Table 3. Aspects of internal lean practices in SCQM

\begin{tabular}{|c|c|c|c|}
\hline $\begin{array}{l}\text { Aspects of Internal } \\
\text { lean practices }\end{array}$ & In-depth & Case A & Case B \\
\hline $\begin{array}{l}\text { The company } \\
\text { regularly conducts } \\
\text { quality audits }\end{array}$ & \multicolumn{3}{|c|}{ Each stage of production line has a quality team with QC/QA department to control quality. } \\
\hline $\begin{array}{l}\text { Using standard } \\
\text { components }\end{array}$ & \multicolumn{3}{|c|}{ It is necessary to apply different quality standards, according to the regulations of the product's composition. } \\
\hline $\begin{array}{l}\text { Cost is emphasized in } \\
\text { the product design } \\
\text { process }\end{array}$ & $\begin{array}{l}\text { A supply chain process that } \\
\text { wants to achieve quality } \\
\text { must be cost effective. } \\
\text { Therefore, managing costs } \\
\text { in the supply chain will } \\
\text { promote SCQM more } \\
\text { effectively. }\end{array}$ & $\begin{array}{l}\text { The company has a technical design } \\
\text { department, which verifies unnecessary } \\
\text { design to recommend revoking for } \\
\text { decreasing production cost. } \\
\text { The company always considers the } \\
\text { current cost, one-time cost, multiple } \\
\text { cost. When focusing on cost, the quality } \\
\text { may be reduced a part. When } \\
\text { mentioning to cost, the company always } \\
\text { wants both parties to gain Win-Win } \\
\text { profit more than only one profitable } \\
\text { party. }\end{array}$ & $\begin{array}{l}\text { On the whole, everything is calculated } \\
\text { by money, just when we consider the } \\
\text { prestige level between long-term } \\
\text { partners in the supply chain, we can } \\
\text { develop the supply chain together. }\end{array}$ \\
\hline $\begin{array}{l}\text { The quality system in } \\
\text { our company is } \\
\text { continuously } \\
\text { improved. }\end{array}$ & $\begin{array}{l}\text { The enterprise musts } \\
\text { determine and standardize } \\
\text { the process of the } \\
\text { enterprise as one of } \\
\text { prerequisites affecting } \\
\text { SCQM. }\end{array}$ & $\begin{array}{l}\text { When defining process, all parts need to } \\
\text { know what they do, what they are good } \\
\text { at, which stage must be concentrated to } \\
\text { improve and let the partner know what } \\
\text { we do to create a clear system, to } \\
\text { minimize the ambiguity between the } \\
\text { parties. }\end{array}$ & $\begin{array}{l}\text { Definitely needed and it will push to } \\
\text { SCQM, as it relates to the prestige and } \\
\text { commitment to the business. If we } \\
\text { don't have the process to manage } \\
\text { orders in supply chain, the orders will } \\
\text { be delayed. Therefore, building } \\
\text { standardized processes in supply } \\
\text { chain and following the set processes } \\
\text { properly is very necessary and } \\
\text { important }\end{array}$ \\
\hline
\end{tabular}

\subsection{Supplier Focus}

Supplier focus is a process of quality control to get detail information on quality performance. Hence, suppliers are chosen based on top quality criteria, participating in suppliers' activities with evaluation, accreditation and feedback programs. The results show that focusing on supplier will help businesses control quality of operations better from the earliest stage.

In addition, according to some experts, the small and medium enterprises do not participate in quality-related activities of suppliers. Although they are interested in, they most choose to find suppliers in a way that suits their requirements instead of focusing on one supplier. 
Table 4. Aspects of supplier focus in SCQM

\begin{tabular}{|c|c|c|c|}
\hline $\begin{array}{l}\text { Aspects of Supplier } \\
\text { focus }\end{array}$ & In-depth & Case A & Case B \\
\hline $\begin{array}{l}\text { The company regularly } \\
\text { conducts supplier } \\
\text { quality audit }\end{array}$ & $\begin{array}{l}\text { Internal assessment programs } \\
\text { are required. If there is no } \\
\text { internal assessment, we will not } \\
\text { know where our partners are, } \\
\text { where our business is, how the } \\
\text { quality of our products and our } \\
\text { suppliers are. Therefore, } \\
\text { supplier test and evaluation } \\
\text { programs will promote } \\
\text { partnerships and promote } \\
\text { SCQM for businesses. }\end{array}$ & $\begin{array}{l}\text { The company also must } \\
\text { create their own evaluation } \\
\text { program to be able to suit } \\
\text { with suppliers not attached to } \\
\text { headquarter. }\end{array}$ & $\begin{array}{l}\text { Internal assessment programs are required, } \\
\text { but internal assessment is also very } \\
\text { difficult when building business based on } \\
\text { relationships. The common commitment } \\
\text { between top management, it is necessary } \\
\text { and compulsory to have a commitment and } \\
\text { agreement in mutual assessment. If there is } \\
\text { no internal assessment, then we will not } \\
\text { know where our partners are, where our } \\
\text { business is, how the quality of our products } \\
\text { and our suppliers are... }\end{array}$ \\
\hline $\begin{array}{l}\text { The company has } \\
\text { detailed information } \\
\text { about supplier } \\
\text { performance }\end{array}$ & $\begin{array}{l}\text { The evaluation not only stop at } \\
\text { the internal functions of the } \\
\text { company but must also be } \\
\text { deployed to the suppliers of the } \\
\text { company, so that SCQM can be } \\
\text { synchronized from the earlier } \\
\text { stage of the supply chain. }\end{array}$ & $\begin{array}{l}\text { It will be a way to help them } \\
\text { see in the process what are } \\
\text { needed to change, what are } \\
\text { needed to maintain and } \\
\text { promote. }\end{array}$ & $\begin{array}{l}\text { It is very important to evaluate suppliers } \\
\text { through KPIs and promote SCQM. } \\
\text { Because there is still the existence of } \\
\text { relationship-based suppliers, and they do } \\
\text { not based on the quality of work to grow. } \\
\text { Following the company's experience, it is } \\
\text { necessary to evaluate suppliers through } \\
\text { KPI to select. }\end{array}$ \\
\hline $\begin{array}{l}\text { The company has a } \\
\text { formal program for } \\
\text { evaluating and } \\
\text { recognizing suppliers }\end{array}$ & $\begin{array}{l}\text { Currently, the evaluation of the } \\
\text { supplier may be from a } \\
\text { business or a third party to } \\
\text { ensure legal status. } \\
\text { The evaluation of suppliers at } \\
\text { the company is frequent, } \\
\text { requiring suppliers to follow } \\
\text { standards. } \\
\text { Whether a business is big or } \\
\text { small, it is necessary to } \\
\text { consider and select suppliers to } \\
\text { build quality for the supply } \\
\text { chain and develop together. }\end{array}$ & $\begin{array}{l}\text { Depending on the type of } \\
\text { goods, the flow of } \\
\text { materials...which goods are } \\
\text { strategic and which goods are } \\
\text { not. The critical items that } \\
\text { should be paid more attention } \\
\text { to quality, price, delivery and } \\
\text { the less important items that } \\
\text { should be considered on } \\
\text { quantity and service level: } \\
\text { delivery, price... }\end{array}$ & $\begin{array}{l}\text { Must consider what customers want. If the } \\
\text { customer wants our company to develop } \\
\text { sustainably, plan to build the factory. } \\
\text { Therefore, consideration must be based on } \\
\text { trust and a commitment to provide a } \\
\text { long-term supply of suppliers. }\end{array}$ \\
\hline $\begin{array}{l}\text { Product quality is } \\
\text { considered as the most } \\
\text { important factor for } \\
\text { selecting suppliers }\end{array}$ & The company regards product qu & lity as the most important factor & or selecting suppliers. \\
\hline $\begin{array}{l}\text { Feedback on the } \\
\text { performance of } \\
\text { suppliers' products. }\end{array}$ & \multicolumn{3}{|c|}{ The company always gives feedback on the performance of suppliers' products. } \\
\hline
\end{tabular}

\subsection{Strategic Supplier Partnership}

Strategic supplier partnership is the process of establishing mutually beneficial relationships with suppliers, participating in the new product design process, supporting suppliers to improve their capabilities, participating in decides suppliers sourcing and building long-term relationships with main suppliers.

In addition, according to some experts, small businesses cannot interfere with suppliers' sourcing, and do not seek to improve suppliers' capacity because they have not established a partnership relationship together. 
Table 5. Aspects of strategic supplier partnership in SCQM

\begin{tabular}{|c|c|c|c|}
\hline $\begin{array}{l}\text { Aspects of strategic } \\
\text { supplier partnership }\end{array}$ & In-depth & Case A & Case B \\
\hline $\begin{array}{l}\text { The company establishes } \\
\text { a win-win relationship } \\
\text { with our suppliers. }\end{array}$ & \multicolumn{3}{|c|}{$\begin{array}{l}\text { Process management for the supply chain is an extremely complex system. It requires working between } \\
\text { multiple divisions with multiple members of the supply chain, so the relationship with the supply chain } \\
\text { affects SCQM performance. }\end{array}$} \\
\hline & $\begin{array}{l}\text { Currently, many Vietnamese } \\
\text { companies use bank loans, and banks } \\
\text { often introduce suppliers to businesses. } \\
\text { This makes businesses try to establish } \\
\text { good relationships with suppliers to } \\
\text { ensure that suppliers supply good }\end{array}$ & $\begin{array}{l}\text { If the relationship is good, } \\
\text { communication will be better, } \\
\text { and the requirements of both } \\
\text { parties will be easier. }\end{array}$ & $\begin{array}{l}\text { It is necessary to determine the } \\
\text { relationship between internal } \\
\text { supply chains and partners of } \\
\text { the supply chain. Since then, } \\
\text { managing of those relationships } \\
\text { will promote SCQM. }\end{array}$ \\
\hline
\end{tabular}

Suppliers' involvement in new product development process

The company aids suppliers in increasing their capabilities

The company participates in sourcing decisions of suppliers

quality.

Large businesses often stand in high positions and require their supplier's response their requests, including materials purchased from suppliers because the percentage of revenue from businesses is huge for suppliers.

The suppliers are actively involved in our new product development process

The information flow in the supply chain is very important.

In addition to the flow of materials managed from the relationship among the functional divisions, the information flow is one of the factors promoting SCQM.
Finally, the requirements in SCQM will also be transmitted in the supply chain in both directions, if it is clearer, we will know what issues need to be improved and what issues need to be solved.
The information flow is very important in the communication and exchange process so that it can operate working and supply chain efficiently

Certainly, this is an important factor. Because suppliers are partners in the supply chain of businesses, businesses must train, and communicate with them ideas about customer's change to work together more effectively.

The partners will make it easier for the company to train their suppliers. That's why we need strategic partners to develop and solve quality issues in the supply chain together.

\begin{abstract}
Vietnamese suppliers do not insufficiently have a strict management model, so they cannot control their sources of raw materials. Instead, two important criteria to choose suppliers are legal and certification of quality standards.
\end{abstract}

Long-term cooperative The company has established long-term cooperative relations with suppliers. relations with suppliers.

\subsection{Customer Focus}

Customer focus is reflected in the company's follow-up about the expectation of the customer regarding quality in the future, through customer satisfaction surveys, handling quality-related complaints, helping customers find the assistance easier, and interacting with customers to establish reliability, responsiveness and different standards. All experts and the company cases gave very satisfactory results.

According to the content conducting annual customer satisfaction surveys on quality, experts say that for large size companies they will have market surveys. For small and medium enterprises, after fulfill the orders, they will ask if their customers are satisfied and every year they visit their customers. 
Table 6. Aspects of customer focus in SCQM

\begin{tabular}{|c|c|c|}
\hline $\begin{array}{l}\text { Aspects } \\
\text { customer focus }\end{array}$ & In-depth & Case A \\
\hline $\begin{array}{lr}\text { Follow-up } & \text { with } \\
\text { customers } & \text { for } \\
\text { quality/service } & \\
\text { feedback } & \end{array}$ & $\begin{array}{l}\text { Most of foreign companies focus } \\
\text { on quality of product because it is } \\
\text { the core to create customers' } \\
\text { trust. } \\
\text { Customers not only evaluate a } \\
\text { business through its products, but } \\
\text { also the support activities' quality }\end{array}$ & $\begin{array}{l}\text { Reaching the customers' desired level is more important than exceeding it, } \\
\text { because if the company meet the customers' needs, they will buy more goods, } \\
\text { but the problems that businesses encounter also increase. Therefore, it is } \\
\text { important to meet the quality standards that customers want. The second } \\
\text { important point is that quality standards must be stable and not change at too } \\
\text { high, too low, SCQM will not be effective. }\end{array}$ \\
\hline
\end{tabular}

also the support activities' quality to bring products to customers.

Thus, following to customers' quality response / service will promote SCQM.

Determination of Focusing on customer needs is a future customer survival condition of the small expectations and medium enterprises. They surveyed customer satisfaction right after the customer's orders. The quality of information in SCQM is a channel helping customers understand what the business is doing, so this plays an important role to promote SCQM.

There is a lot of information such as technical knowledge, internal, product...but, we must know what should be said and what shouldn't. Besides, the information is often transmitted with top-down structure, so the impact on information quality management will not promote much on SCQM.

Dealing with Quality-related customer complaints are treated with top priority.

quality-related

customer

complaints in high

priority

Making it easier for customers seeking assistance

Customers are increasingly interested in the issues relating the quality of products which they buy.
Of course, customers and businesses are those evaluating the final quality of the company's products and services, they will convey the information, what is good, what is weak and what is missing... If the business focuses on customer's requirements and the products are suitable for the market, make sure that even if your product is not the best but it will be the most suitable product in the market.
Because the requirements of customers are different, the supply chain quality information management will also be different for different customers.
This is a business to business firm, so there will be regular meetings with customers about product and service problems, then they can re-evaluate costs, delivery, attitudes, etc.

\begin{tabular}{|c|c|c|}
\hline $\begin{array}{l}\text { Interaction with } \\
\text { customers to set } \\
\text { reliability, } \\
\text { responsiveness, } \\
\text { other standard }\end{array}$ & $\begin{array}{l}\text { Interaction with customers to } \\
\text { establish reliability, } \\
\text { responsiveness and other } \\
\text { standards is one of the ways to } \\
\text { improve the effective quality of } \\
\text { the supply chain because }\end{array}$ & $\begin{array}{l}\text { This is a business to business } \\
\text { firm, so there will be regular } \\
\text { meetings with customers about } \\
\text { product and service problems, } \\
\text { then they can re-evaluate costs, } \\
\text { delivery, attitudes, etc. }\end{array}$ \\
\hline
\end{tabular}
customers will be the final people evaluating products and their quality that company provides.
Depending on whether it is an internal customer or a final customer of the business. Firms having many customers from Europe, Africa, Asia, and America... are difficult to choose the way to follow. They cannot satisfy all needs of all customers, but they are willing to satisfy the minimum that customers need. Because the business has many different customers and there are always conflicts among customers' requirements such as European customers with their own set of requirements, America customers with other set of requirements, Africa customers with another set of requirements, etc. Therefore, it is more important to adhere to the common rules to meet the standard needs of customers.

Quality management and customer relationships depend on what the customer's requirements. When the companies know requirements of customers, they can have a common element to satisfy customers' needs.

\section{Discussion}

According to this result, some discussions are followed up in below:

Firstly, in order to implement and achieve SCQM well, commitment from the management board is more important and necessary than developing knowledge and skills. Only when leaders realize the benefits and efficiency of SCQM as well as the urgency to implement it, they would have commitment, concern, support and 
priority to carry out establishment activities. Enterprises need to send their leaders to participate in such seminars, workshops on the subject of improvement in supply chain quality and efficiency to broaden their knowledge and to learn from experts and other business leaders as well. Thereby, they can also take this opportunity to build more relationships and to evaluate their enterprises' positions compared to other competitors in and outside the industry.

Secondly, human resource planning must be aligned with the actual needs of projects and functional departments. If it does not derive from simultaneous needs, it may result in labor redundancy and low productivity due to the fact that work which should be broken down into many parts is split to many workers. This task should always call for people and take place continuously even how stable the systems operate, especially in process improvement, system measurement and assessment improvement activities. Ability and attitude should always be considered when recruit employees in SCQM field. Actually, training and educating those who may not have enough knowledge and required skills, but possess potential competence and positive, ready - to - learn attitude are quite easy and fast. When employees have gained the foundation of SCQM, the spirit of participation in management and maintenance ought to be promoted. For quality management team, team working activities will provide an open environment for each team member to learn from each other. Additionally, external consultant organizations will assist in forming the right directions in SCQM. Also, the working environment will promote the implementation as well as support for more effective communication. By sharing the information, employees will be encouraged to implement SCQM continuously not only in the issue - review meetings but also in daily activities in which supply chain staffs play crucial roles.

Thirdly, on the aspect of internal lean practices, company should identify the smaller goals from its strategies and overall goals that need to be achieved, then combine them with internal enterprise resource evaluation to arrange the order and priority for each goal. Based on that, the company should split the supply chain process into specific stages. At each stage, clear milestones must be set in the process and the relationships between departments. At the same time, in each stage, tasks, projects and working plans must also be defined and prioritized. This stepwise procedure allows each task to be closely aligned with the strategies and goals from the general to the details, in the right order and clearly conducted, which enables a logical and effective information flow. Thereby, KPIs for each department will be assessed through its operational efficiency. Logistics department must always ensure shipping of products, flexibly handling of issues. Purchasing department needs to determine an effective procurement plan, etc. As a consequence, supply chain cost is determined for each specific job, which helps to identify the abnormalities for supply chain quality improvements.

Fourthly, on the aspect of supplier focus and strategic supplier partnership, the partnership between companies and their suppliers should be enhanced through activities to build, develop and maintain long-term cooperation with each other, especially essential, strategic, irreplaceable suppliers. Companies can organize visits to suppliers for their managers and suppliers can do vice versa. Companies should also carry out a regular supplier quality assessment and proactively propose solutions to handle disturbance as well as improve processes or output quality control. Long-term relationships with suppliers enable better negotiation and optimal solutions for sales policy and material prices. Besides, the quality of raw materials is controlled proactively and strictly to meet up with the requirements of enterprises, which ensures quality right from the beginning of the production process based on Lean Six Sigma philosophy - First time through. Moreover, right selection of suppliers results in the efficiency of the supply chain. In addition, enterprises that are always involved in supplier' quality control activities are more reliable and synchronized. By conducting KPIs assessment, enterprises will be more likely to select and evaluate suitable suppliers.

Finally, on the aspect of customer focus, it is identified that regular two-way information exchange and building cooperative relationships with customers are just as important as with suppliers, especially with a few key customers who account for a significant proportion of total sales. For B2B businesses whose customers are also other companies, organizing company visits may create more opportunities for both management boards to meet and tighten their cooperation. In case the implementation of SCQM at the customer's factory is assessed not yet available or imperfect, the enterprise should proactively propose and consult on improvement solutions. It is even better when the customer allows the company to support in the implementation phase to ensure high quality end - to - end supply chain. For numerous B2C businesses in which products are distributed across channels and end - users are mostly individuals, the implementation is carried out in a different manner, business activities should be focused on customer care rather than consultancy or coordination. Sales department or customer relationship department should periodically contact agents, supermarkets, distributors or even individual customers via phone calls to find out more about quality, employees' attitudes, level of customer satisfaction, thereby adjusting and improving its business through their comments and feedbacks. Simultaneously, the 
proactive market anticipation as well as better analysis and forecast could be achieved by conducting actual market research or referring to previous studies to capture new demands and consumption trends.

\section{Conclusion}

Consequently, through literature review, seven in-depth interviews and two case studies, this study identifies the six critical aspects of supply chain quality management practices having the impact on firms' performance in Vietnam, specifically:

- Top management support: actively participate in quality management and improvement process; strongly encourage employee involvement in quality management and improvement activities; discuss many quality-related issues in top management meetings; strongly encourage supplier involvement in quality management and improvement activities; empower suppliers to solve quality problems.

- Human resource development: Train employees on how to use quality management method (tools); educate quality awareness to employees; improve working conditions in order to recognize employee quality improvement efforts; encourage employees to report work problems in our company; encourage employees to fix problems they find.

- Internal lean practices: regularly conduct quality audits; use standard components; deploy quality, emphasize cost in the product design process; continuously improve the quality system in our company.

- Supplier focus: regularly conduct supplier quality audit; have detailed information about supplier performance; have a formal program for evaluating and recognizing suppliers; regard product quality as the most important factor for selecting suppliers; always give feedback on the performance of suppliers' products.

- Strategic supplier partnership: establish a win-win relationship with our suppliers; actively involve in the new product development process; aid suppliers in increasing their capabilities; participate in sourcing decisions of suppliers; establish long-term cooperative relations with suppliers.

- Customer focus: follow-up with customers for quality/service feedback; determination of future customer expectations; quality-related customer complaints are treated with top priority; making it easier for customers seeking assistance; interaction with customers to set reliability, responsiveness, other standard.

Accordingly, it is suggested that in order achieve effective SCQM, $(a)$ it is necessary to recruit people who have moderate knowledge about SCQM and the attitude to implement SCQM effectively; (b) the learning ability of each employee plays an important role in the supply chain quality improvement and efficiency promotion for enterprises; (c) experts will help enterprises have a more general view of the market who also involve in adjusting the orientation towards SCQM of the management board and affect business efficiency; (d) a dynamic working environment that is innovation and improvement driven as well as an open working environment for all employees will be a place for effective SCQM implementation; (e) partner relationship in the supply chain positively affects SCQM due to the complex nature of process control and improvement; $(f)$ business efficiency could be promoted by improving the information flow between functional departments and among chains in the supply chain; (g) a better SCQM implementation could be realized through will ensure through mutual assessment activities with the evaluation of KPIs of departments (logistics, warehouse, distribution) in the supply chain; and $(h)$ top management support is more important in SCQM practices.

In short, this study provides the findings based on qualitative techniques which help supply chain managers in companies in Vietnam improve their business. These results are the basis for the future research of supply chain quality management in the following directions, such as differences in types of industry, differences in activity levels by activity area, establishment time, firm size, etc. Also, it is interesting for further studies based on quantitative approaches to supplement or debate on these results.

\section{Acknowledgments}

This research is funded by Ho Chi Minh City University of Technology - VNU-HCM under grant number C2017-20-42, which is much appreciated. Also, the author would like to express the sincere thanks to the supply chain experts, supply chain managers of steel company A, packaging company B, and special thanks to Mr. Nguyen Thanh Hiep for the sincere help in data collection.

\section{References}

Azar, A., Kahnali, R. A., \& Taghavi, A. (2010). Relationship between supply chain quality management practices and their effects on organizational performance. Singapore Management Review, 32(1), 45-68. 
Chaghooshi, A. J., Soltani-Neshan, M., \& Moradi-Moghadam, M. (2015). Canonical Correlation Analysis between Supply Chain Quality Management and Competitive Advantages. Foundations of Management, 7(1), 83-92. https://doi.org/10.1515/fman-2015-0027

Creswell, J. W. (2009). Research design: Qualitative, quantitative and mixed methods approaches (3rd ed.). Los Angeles: Sage Publications.

Flynn, B. B., \& Flynn, E. J., (2005). Synergies between supply chain management and quality management: emerging implications, International Journal of Production Research, 43(16), 3421-3436. https://doi.org/10.1080/00207540500118076

Kannan, V. R., \& Tan, K. C. (2005). Just in time, total quality management, and supply chain management: understanding their linkages and impact on business performance. Omega, 33(2), 153-162. https://doi.org/10.1016/j.omega.2004.03.012

Kaynak, H., \& Hartley, J. L. (2008). A replication and extension of quality management into the supply chain. Journal of Operations Management, 26(4), 468-489. https://doi.org/10.1016/j.jom.2007.06.002

Kuei, C. H., \& Madu, C. N. (2001). Identifying critical success factors for supply chain quality management (SCQM). Asia Pacific Managemenl Review, 6(4), http://dx.doi.org/10.6126\%2fAPMR.2001.6.4.02

Lin, C., Chow, W. S., Madu, C. N., Kuei, C. H., \& Yu, P. P. (2004). A structural equation model of supply chain quality management and organizational performance. International Journal of Production Economics, 96(3), 355-365. https://doi.org/10.1016/j.ijpe.2004.05.009

Lin, C., Kuei, C. H., \& Chai, K. W. (2013). Identifying critical enablers and pathways to high performance supply chain quality management. International Journal of Operations \& Production Management, 33(3), 347-370. https://doi.org/10.1108/01443571311300818

Lin, L., \& Gibson, P. (2011). Implementing supply chain quality management in subcontracting system for construction quality. Journal of System and Management Sciences, 1(1), 46-58.

Lo, V. H. Y., \& Yeung, A. (2006). Managing quality effectively in supply chain: A preliminary study. Supply Chain Management: An International Journal, 11, 208-215. https://doi.org/10.1108/13598540610662103

Lo, V. H. Y., Yeung, A. H. W., \& Yeung, A. C. L., (2007). How supply quality management improves an organization's quality performance: a study of Chinese manufacturing firms. International Journal of Production Research, 45(10), 2219-2243. https://doi.org/10.1080/00207540600597179

Nguyen, M. (2016). Chuỗi cung ứng và cuộc chơi của doanh nghiệp Việt Nam trong bối cảnh mới. Vietnam finance.

Retrieved

from http://vietnamfinance.vn/chuoi-cung-ung-va-cuoc-choi-cua-doanh-nghiep-viet-trong-boi-canh-moi-2016101 6030517685.htm

Nguyen, N. T. D., Le, P. V., Nguyen, T. H., \& Huynh, T. P. L. (2017). Perspectives on Supply Chain Quality Management Research. Science and Technology Development Journal, 20(Q4-2017), 52-60.

Nosratpour, M., \& Hamid, A. B. A. (2015). The Impact of SCQM Practices on Organizational Performance. International Journal of Enhanced Research in Management \& Computer Applications, 4(5), 5-15.

Okoth, O. T., \& Ochieng, O. S. (2016). Supply Chain Quality Management Practices and Performance of Pharmaceutical Distributors and Wholesalers in Mombasa, Kenya. International Journal of Managerial Studies and Research, 4(8), 94-102. https://doi.org/10.20431/2349-0349.0408008

Robinson, C. J., \& Malhotra, M. K. (2005). Defining the concept of supply chain quality management and its relevance to academic and industrial practice. International Journal of Production Economics, 96(3), 315-337. https://doi.org/10.1016/j.ijpe.2004.06.055

Sila, I., Ebrahimpour, M., \& Birkholz, C. (2006). Quality in supply chains: an empirical analysis. Supply Chain Management: An International Journal, 11(6), 491-502. https://doi.org/10.1108/13598540610703882

Soares, A., Soltani, E., \& Liao, Y. Y. (2017). The influence of supply chain quality management practices on quality performance: an empirical investigation. Supply Chain Management: An International Journal, 22(2), 122-144. https://doi.org/10.1108/scm-08-2016-0286

Zhang, Z., Waszink, A., \& Wijngaard, J. (2000). An instrument for measuring TQM implementationfor Chinese manufacturing companies. International Journal of Quality \& Reliability Management, 17(7), 730-755. https://doi.org/10.1108/02656710010315247

Zeng, J., Phan, C. A., \& Matsui, Y. (2013). Supply chain quality management practices and performance: An empirical study. Operations Management Research, 6(1-2), 19-31. https://doi.org/10.1007/s12063-012-0074-x 


\section{Copyrights}

Copyright for this article is retained by the author(s), with first publication rights granted to the journal.

This is an open-access article distributed under the terms and conditions of the Creative Commons Attribution license (http://creativecommons.org/licenses/by/4.0/). 